\title{
EVALUATION OF THE ACUTE AND SUBCHRONIC TOXICITY STUDIES OF BARLERIA BUXIFOLIA LINN. IN ALBINO RATS
}

\author{
MANOHAR REDDY ${ }^{1,2}$, RAJA SUNDARARAJAN ${ }^{2 *}$ \\ ${ }^{1}$ Department of Pharmacology, P. Rami Reddy Memorial College of Pharmacy, Kadapa, Andhra Pradesh, India. ${ }^{2}$ Department of \\ Pharmaceutical Chemistry, GITAM Institute of Pharmacy, GITAM (Deemed to be University), Visakhapatnam, Andhra Pradesh, India. \\ Email: sraja61@gmail.com
}

Received: 07 January 2021, Revised and Accepted: 23 February 2021

ABSTRACT

Objective: The fundamental reason for this examination was to look at the acute and subchronic toxicity studies of chloroform and methanol extracts of Barleria buxifolia Linn. (Acanthaceae) on creature models according to the OECD rules 407 and 425, respectively.

\begin{abstract}
Methods: In acute oral toxicity, study a single oral dosages of $5000 \mathrm{mg} / \mathrm{kg}$ body weight of chloroform and methanol extracts was given individually to rats and watched them for 2 weeks for the discovery of acute changes and for its mortality any. During acute oral toxicity study period, no mortality was seen without any signs of intense changes. Further, it was executed the subchronic toxicity of extracts. Barleria buxifolia extracts (chloroform and methanol) were independently given every day at dosages of 250 and $500 \mathrm{mg} / \mathrm{kg}$ body weight for 90 days to recognize the progressions any at subchronic poisonousness levels. Towards the finish of the experimentation the serum tests of trail creatures were gathered and watched for any progressions in haematological, biochemical and histopathological boundaries
\end{abstract}

Results: All parameters of treated group were shown unaltered changes throughout the study period when compared with that of normal group. The outcomes propose that the oral organization of chloroform and methanol extracts of Barleria buxifolia did not raise any huge poisonous impacts when contrasted with that of control animals.

Conclusion: Hence, the extracts may be safe for therapeutic use and as an alternative system of medicine.

Keywords: Acute toxicity study, Barleria buxifolia Linn., Biochemical parameters, Histopathology, Subchronic toxicity study.

(C) 2021 The Authors. Published by Innovare Academic Sciences Pvt Ltd. This is an open access article under the CC BY license (http://creativecommons.org/ licenses/by/4.0/) DOI: http://dx.doi.org/10.22159/ajpcr.2021v14i4.40721. Journal homepage: https://innovareacademics.in/journals/index.php/ajpcr

\section{INTRODUCTION}

Recently created drugs before going to use on people for restoring infections, it must be assessed for its toxicity studies. The significance in leading the toxicity studies is not just to assess for its well-being yet additionally to realize the conceivable poisonous impacts delivered by the utilization of the created drugs [1]. Toxicity studies are fundamentally done as acute toxicity study, subacute toxicity study, and chronic toxicity study according to the organization for economic corporation and development (OECD) rules.

The OECD board of specialists characterizes acute toxicity as "the unfavorable impact happening inside a brief time frame of (oral) organization of a solitary portion of a substance or different dosages given inside 24 h." Furthermore, subchronic toxicity studies as "the antagonistic impacts happening as consequence of the rehashed every day (oral) dosing of a synthetic to test for the most part for 1-3 months." Subchronic toxicity testing gives the important data on the total harmfulness of a compound at low portion delayed introduction and wide assortment of unfriendly impact can be distinguished. The outcome from such examinations can give data which will help in choosing dose level. Normally, the toxicity studies are completed in shorter live animals, for example, rodents and 1 year concentrates in longer lived animals of dogs and monkeys. The normal courses of administration used in acute toxicity studies are oral and in subacute and chronic toxicity examines are oral, dermal, and respiratory courses [2].

The class Barleria is under bush topographically generally disseminated in tropical nations. It is the third biggest variety in the family Acanthaceae with 300 species among that 32 species are accounted for from India. As of late, the entire plant of family Barleria picked up the significance for the treatment of different diseases such as liver issues, diabetes, neurological issues, immunodeficiency, inflammation, ulcers, HSV-2 viral infections, and so on [3].

Among the genus Barleria, Barleria cristata is proved for antioxidant activity, thrombolytic activity, membrane stabilizing activity, antimicrobial activity [4], and antidiabetic activity [5]. Barleria gibsoni is proved for anti-inflammatory activity, antioxidant, antiulcer activity, and anthelmintic activity [6,7]. Barleria montana is proved for antibacterial activity [8], hepatoprotective activity [9], and antidiabetic activity [5]. Experimentally, Barleria cuspidate Heyne ex Nees has proved for wound healing property [9] and hepatoprotective activity [10].

Barleria buxifolia Linn. is one of the important species in Barleria belongs to the family Acanthaceae. It is a shrub found in waste places, poor soils. and along road ways [11]. Barleria buxifolia is proved for anthelmintic activity [12], antifeedant activity [13], anxiolytic activity, antidepressant activity [14], and prophylactic and curative activities [15]. Due to the adverse effects and also with the development of resistance with the use of synthetic drugs, nowadays, the usage of plant-derived drugs is become popular in the world. Latest survey reveals that chronic usage of medicinal plants shows potential toxic effects and makes the step to evaluate the toxicological effects of any medicinal plant extracts intended to be used clinically or pre-clinically [16]. The present study was aimed to investigate the toxicity study of Barleria buxifolia Linn. to increase the assurance in their safety to humans to treat versatile ailments.

\section{METHODS}

Collection of plant material

Fresh whole plant of Barleria buxifolia Linn. (Acanthaceae) was pull together from Chittoor districts in the areas of Tirumala Hills and Tirupati surroundings and authentified by Dr. K. Madava Chetty, 
Professor, Department of Botany, Sri Venkateswara University, Tirupati, Andhra Pradesh, India. Voucher specimen (No: BB- 1418) of this plant has been kept in the P. Rami Reddy Memorial College of Pharmacy, Kadapa, Andhra Pradesh, India.

\section{Plant material}

The gathered entire plant of Barleria buxifolia was washed with running water, cut into little pieces, and shade dried at room temperature to maintain a strategic distance from loss of phytoconstituents of plant. The total shade dried materials pounded for powder and sieved up to 80 meshes. At that point, it was homogenized to fine powder and put away in airtight compartment for additional toxicity considers.

\section{Preparation of plant extracts}

Whole plant powder of Barleria buxifolia was extracted successively with two different solvents such as chloroform $\left(30-60^{\circ} \mathrm{C}\right)$ and methanol $\left(50-70^{\circ} \mathrm{C}\right)$ in a Soxhlet apparatus in batches of $500 \mathrm{~g}$ each. The overabundance solvent was expelled from extract utilizing a rotary vacuum evaporator and later on concentrated on a water bath. The rate yield of the extract was determined. At last, dried extract was put away in desiccators for toxicity studies.

\section{Procurement of animals and maintenance}

Albino rats of either sex, gauging the body weight of 150-250 g were acquired from Sri Venkateswara Enterprises, Bengaluru, India. Animals were kept up according to rules of National Institute of Nutrition (NIN) animal client manual. Animals are adjusted for 10 days to our creature house, kept up at temperature of $22^{\circ} \mathrm{C}$ to $\pm 2^{\circ} \mathrm{C}$. The animal was directed by a $12 \mathrm{~h}$ light, $12 \mathrm{~h}$ dark calendar. Five animals are housed per cage estimated $41 \mathrm{~cm}$ length, $28 \mathrm{~cm}$ width, and height of $14 \mathrm{~cm}$. Paddy husk was utilized for bedding, and on elective day, bedding was changed and washed altogether with water alongside Domex, a disinfectant and detergent. The rats were benefited from a standard pellet diet bought from Suresh organizations, Hyderabad, and water not obligatory. The examination convention was investigated and endorsed by the Institutional Animal Ethical Committee (IAEC) and trials were led according to the rules of CPCSEA. Reg. Number: 1423/PO/Re/S/11/CPCSEA, date October 30, 2017.

\section{Acute oral toxicity study}

An oral acute toxicity investigation of chloroform and methanol extracts of Barleria buxifolia was performed individually by the Organization for Economic Cooperation and Development (OECD) rule 425 on rodents [17], where the breaking point test portion of $5000 \mathrm{mg} / \mathrm{kg}$ was utilized. All the animals were kept $3 \mathrm{~h}$ fasting before to explore different avenues regarding free abundance to water. A solitary oral dosages of $5000 \mathrm{mg} / \mathrm{kg}$ body weight of the individual chloroform and methanol extracts were given utilizing oral gavage for present moment (i.e., $48 \mathrm{~h}$ ) and long term (i.e., 14 days) to the rats. Before dose administration, the body weight of every animal was resolved and the dose was determined by the body weight. Animals were seen to distinguish intense changes in morphological and conduct reactions, unconstrained action, touchiness, corneal reflex, tremors, spasms, salivation, loose bowels, and torpidity assuming any and furthermore observed for any mortality throughout toxicity study [18].

\section{Subchronic toxicity study}

The oral subchronic toxicity study was done by OECD rule 407 . The animals were partitioned into five groups of six rats each was kept in five separate pens. Group I was kept as should be expected normal control and Groups II-V were kept as tested groups which received the dosages as follows.

Group I: Normal control animals received normal clean drinking water ad libitum.

Group II: Animal received chloroform extract of Barleria buxifolia (CEBB) $250 \mathrm{mg} / \mathrm{kg}$ per orally.

Group III: Animal received chloroform extract of Barleria buxifolia (CEBB) $500 \mathrm{mg} / \mathrm{kg}$ per orally.

Group IV: Animal received methanol extract of Barleria buxifolia (MEBB) $250 \mathrm{mg} / \mathrm{kg}$ per orally.
Group V: Animal received methanol extract of Barleria buxifolia (MEBB) $500 \mathrm{mg} / \mathrm{kg}$ per orally.

All the animals in the above groups get their portions as needs be for the examination time of 90 days [19]. Body weight of every animal in group was recorded at first and for like clockwork span till the most recent day of analysis. Following 90 days blood tests of exploratory rats in each group were acquired by retro-orbital with a capillary into Eppendorf tubes without anticoagulant, centrifuged at $400 \times \mathrm{g}$ for 10 min and the serum put away at $4^{\circ} \mathrm{C}$ for estimation of different serum biochemical boundaries, for example, glucose, creatinine, total protein, albumin, globulin, bilirubin, SGOP, SGPT, and ALP and for electrolytes (phosphorus, chloride, and calcium). Other blood tests were gathered into isolated tubes previously covered with trisodium citrate for hematological investigation, for example, RBC, WBC, hemoglobin, platelets, and mean cell volume. Every trial animal was sacrificed in the wake of gathering of blood tests by infusing the phenobarbital infusion for gathering the internal organs to decide the relative organ loads and for histopathological investigations of brain, liver, kidney, heart, and lungs.

\section{Serum biochemical parameters}

Serum glucose, creatinine, total protein, albumin, globulin, bilirubin, SGOT, SGPT, ALP, and electrolytes were determined using a semiautomated analyzer.

\section{Serum glucose determination}

Serum glucose levels were determined using Trinder method (Glucose, GOD-POD) by the addition of reagents present in reagent kit (AGD Biomedicals Pvt. Ltd.). The absorbance of standard and test against reagent blank was measured at $505 \mathrm{~nm}[20,21]$.

\section{Serum creatinine determination}

Serum creatinine levels were ascertained by reagents present in reagent kit (AGD Biomedicals Pvt. Ltd.). The absorbance of standard and test against reagent blank was measured at $520 \mathrm{~nm}$.

\section{Serum total protein concentration}

Serum total protein levels were ascertained using end point assay method acting by the addition of reagents present in reagent kit (Span Diagnostic Ltd.). The absorbance of standard and test against reagent blank was measured at $578 \mathrm{~nm}$. The values of total proteins present in serum were expressed in $\mathrm{g} / \mathrm{dL}$.

\section{Serum albumin concentration}

Serum albumin levels are ascertained using bromocresol green, end point assay method by the addition of reagents present in reagent kit (Span Diagnostic Ltd.). The absorbance of standard and test against reagent blank was measured at $630 \mathrm{~nm}$. The values of albumin present in serum were expressed in $\mathrm{g} / \mathrm{dL}$.

\section{Serum globulins concentration}

Serum globulins levels are ascertained using the equation: Globulins $=$ Total proteins - Albumin And the values are expressed in $\mathrm{g} / \mathrm{dL}$

\section{Serum transaminases (GOT and GPT)}

Serum transaminases (GOT and GPT) were determined by the method of Reitman and Frankel [22] by the addition of reagents present in reagent kit (Span Diagnostic Ltd.). The absorbance of standard and test against reagent blank was measured at $505 \mathrm{~nm}$. Data were communicated as $\mathrm{IUL}^{-1}$.

\section{Serum alkaline phosphatase (ALP)}

Serum alkaline phosphatase (ALP) was ascertained by the method of Kind and King [22] by the addition of reagents present in reagent kit (Span Diagnostic Ltd.). The absorbance of standard and test against reagent blank was measured at $640 \mathrm{~nm}$. Data were communicated as $\mathrm{UL}^{-1}$. 


\section{Serum bilirubin}

Serum bilirubin was evaluated by method of Malloy and Evelyn [23]. The two test tubes were taken and each into was added $0.2 \mathrm{ml}$ of serum test and $1.8 \mathrm{ml}$ of distilled water. To the obscure, $0.5 \mathrm{ml}$ of diazo reagent and to the blank, $0.5 \mathrm{ml}$ of $1.5 \% \mathrm{HCl}$ were included. At last, to each tube, $2.5 \mathrm{ml}$ of methanol was added and afterward permitted to represent $30 \mathrm{~min}$ in ice and absorbance was perused at $540 \mathrm{~nm}$. For a standard curve, the above standard was weakened 1 out of $5 \mathrm{ml}$ methanol. The measure of direct responding bilirubin was resolved also by subbing $2.5 \mathrm{ml}$ of water for $2.5 \mathrm{ml}$ of methanol. Qualities were communicated as $\mathrm{mg} / \mathrm{dl}$.

\section{Hematological analysis}

Red blood cells (RBCs), white blood cells (WBCs), platelets, hemoglobin $(\mathrm{Hg})$, and mean cell volume (MCV) were ascertained with a semiautomated analyzer.

\section{Statistical analysis}

All investigations information were communicated as mean \pm standard error mean (SEM). This statistical analysis was done utilizing oneway ANOVA strategy followed by Dunnett's t-test with SPSS statistical programming for correlation with the control group. $\mathrm{p} \leq 0.05$ was considered as statistically significant.

\section{RESULTS AND DISCUSSION}

From old to introduce period, the people were utilized the herbal drugs and their formulations for restoring ailments as they considered its utilization is sheltered and powerful with insignificant reactions. This suspicion may impact on country populace for the use of this formulation in chronic periods without the consciousness of the toxic impacts. Logical information toward the oral toxicity is fundamental in fixing the doses for herbal formulations as well as to know the conceivable outcomes in safe utilization of these plans [24].

The information acquired with the logical examination on acute and subchronic toxicity reads for herbal plants or herbal formulations may build the trust in their security to people, curiously for use in the improvement of pharmaceuticals. In this way, estimating of the toxicological impacts of any therapeutic plant extract intend to be utilized in animals or people are a basic piece of its evaluation for likely toxic impacts [25]. In this way, the current examination work was meant to assess the chloroform and methanol extracts of Barleria buxifolia for its acute and subchronic toxicity study and to compute the portion run for additional investigations.

\section{Acute oral toxicity study}

The acute oral toxicity study was done on albino rats of either sex at single portion of chloroform and methanol extracts of Barleria buxifolia at $5000 \mathrm{mg} / \mathrm{kg}$ body weight and consistently checked for about 14 days for its and its mortality according to OECD rules 425 . At all the degree of treatment for study period (14 days), all the exploratory rats were endure and show typical conduct in their awareness, touch reaction, sleeping length, development, gripping quality, righting reflex, food admission, water utilization, pinna reflex, corneal reflex, salivation, skin color, and sound reaction, and there is missing in reactions, for example, grooming, tremors, diarrhea, hyper activity, lethargy, convulsions, and morbidity. Subsequently, this outcome tabulated in Table 1 says that there was no aggravation in carbohydrate, protein, fat, and some other metabolisms [26].

\section{Subchronic toxicity study}

The chloroform and methanol extracts of Barleria buxifolia at $5000 \mathrm{mg} / \mathrm{kg}$ body weight given orally are by all accounts safe and the $\mathrm{LD}_{50}$ is considered be $>5000 \mathrm{mg} / \mathrm{kg}$ body weight. All of these results will propose that single oral dosage of chloroform and methanol extracts of Barleria buxifolia were non-poisonous in all intent and purposes at 5000 $\mathrm{mg} / \mathrm{kg}$ body weight. Anyway in instances of various portions utilized in the treatment of chronic issues such as diabetes, malignancy, and so on, regardless of whether it will be protected and have no impact on organ loads, biochemical and hematological boundaries, and electrolyte levels will adjusted by subchronic toxicity study.

\section{Analysis of body weights of each experimental rat}

Subchronic toxicity examines was did with chloroform and methanol extracts of Barleria buxifolia at the dosages of $250 \mathrm{mg} / \mathrm{kg}$ and $500 \mathrm{mg} /$ kg body weight according to the OECD rules 407 [27]. The aftereffects of mean body loads among the diverse rewarded gatherings and control are appeared in Fig. 1 as no noteworthy contrasts despite the fact that there will be increment in body loads continuously. These outcomes will show that the chloroform and methanol extracts of Barleria buxifolia have immaterial degrees of toxicity on the development of the animals.

\section{Measurement of organ weights}

The outcomes in of any adjustments in relative organ loads of each exploratory rat in bunch at end of the experimentation are appeared in Fig. 2. With no essential changes in weights of important organs such as liver, lungs, kidneys and heart will give the non-toxic impact in both control and rewarded groups and supports for the security of Barleria buxifolia.

\section{Serum biochemical parameters}

Following 90 days of study period, the serum biochemical and hematological parameters were assessed for finding the ordinary working of liver, urinary system, and typical electrolyte levels and

Table 1: Acute oral toxicity study of chloroform and methanol extracts of Barleria buxifolia at $5000 \mathrm{mg} / \mathrm{kg}$ body weight in rats

\begin{tabular}{|c|c|c|c|c|}
\hline \multirow[t]{2}{*}{ S. No. } & \multirow[t]{2}{*}{ Observations } & \multicolumn{3}{|c|}{ Response } \\
\hline & & Control & $\begin{array}{l}\text { CEBB } 5000 \\
\mathrm{mg} / \mathrm{kg} \text { b.w }\end{array}$ & $\begin{array}{l}\text { MEBB } 5000 \\
\mathrm{mg} / \mathrm{kg} \mathrm{b.w}\end{array}$ \\
\hline 1. & Consciousness & + & + & + \\
\hline 2. & Grooming & - & - & - \\
\hline 3. & Touch response & + & + & + \\
\hline 4. & Sleeping duration & + & + & + \\
\hline 5. & Movement & + & + & + \\
\hline 6. & Gripping strength & + & + & + \\
\hline 7. & Righting reflex & + & + & + \\
\hline 8. & Food intake & + & + & + \\
\hline 9. & Water consumption & + & + & + \\
\hline 10. & Tremors & - & - & - \\
\hline 11. & Diarrhea & - & - & - \\
\hline 12. & Hyper activity & - & - & - \\
\hline 13. & Pinna reflex & + & + & + \\
\hline 14. & Corneal reflex & + & + & + \\
\hline 15. & Salivation & + & + & + \\
\hline 16. & Skin color & + & + & + \\
\hline 17. & Lethargy & - & - & - \\
\hline 18. & Convulsions & - & - & - \\
\hline 19. & Morbidity & - & - & - \\
\hline 20. & Sound response & + & + & + \\
\hline 21. & Mortality & Alive & Alive & Alive \\
\hline
\end{tabular}

\section{+: Normal, -: Absent}

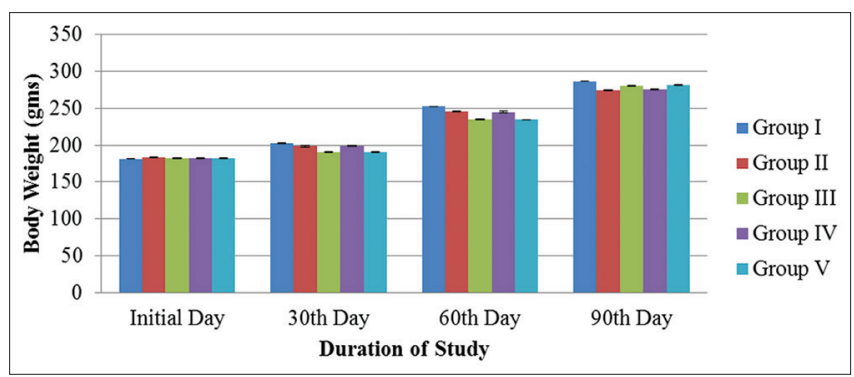

Fig. 1: Effect of chloroform and methanol extracts of Barleria buxifolia Linn. on body weights of experimental rats 
their aftereffects are recorded in Figs. 3 and 4, and electrolytes levels are recorded in Table 2. Serum biochemical parameters, for example, SGOT, SGPT, ALP, and bilirubin of rewarded group do not show huge change when contrasted and that of control groups. The estimations of these biochemical parameters typically gauge as markers of the best possible liver capacity [28]. Further, there is no noteworthy in glucose levels in the treated groups when contrasted with the control group which likewise demonstrates for ordinary working of liver. In addition, levels of serum total protein, albumin, and globulin indicated no critical change when contrasted the treated group animals and that of control group animals [29]. The estimations of serum creatinine will gauge the best possible capacity of urinary system [30], thus with no huge changes in serum creatinine levels of test creatures show the correct working of urinary system in animals treated with Barleria buxifolia.

Likewise, the serum levels of electrolytes, for example, phosphorus, chloride, and calcium indicated no essentialness distinction when contrasted the treated group animals and that of control group

Table 2: Effect of chloroform and methanol extracts of Barleria buxifolia on serum electrolyte levels

\begin{tabular}{lllll}
\hline S. No. & \multirow{2}{*}{ Group } & \multicolumn{3}{l}{ Serum electrolytes levels } \\
\cline { 3 - 5 } & & $\begin{array}{l}\text { Phosphorus } \\
\text { (mg/dl) }\end{array}$ & $\begin{array}{l}\text { Chloride } \\
\text { (mmol/lit) }\end{array}$ & $\begin{array}{l}\text { Calcium } \\
\text { (mg/dl) }\end{array}$ \\
\hline 1. & I & $5.65 \pm 0.108$ & $104.83 \pm 1.04$ & $10.4 \pm 0.2$ \\
2. & II & $5.45 \pm 0.14$ & $104.33 \pm 1.22$ & $10.18 \pm 0.09$ \\
3. & III & $5.63 \pm 0.105$ & $105.16 \pm 0.94$ & $10.16 \pm 0.14$ \\
4. & IV & $5.46 \pm 0.09$ & $104.66 \pm 0.98$ & $10.03 \pm 0.08$ \\
5. & V & $5.4 \pm 0.12$ & $103.83 \pm 1.22$ & $10.21 \pm 0.06$ \\
\hline
\end{tabular}

The values are communicated as mean \pm SEM of six animals in each group shows no significance by utilizing SPSS. Statistical significant test for correlation was done by ANOVA, trailed by Dunnett's " $\mathrm{t}$ " test

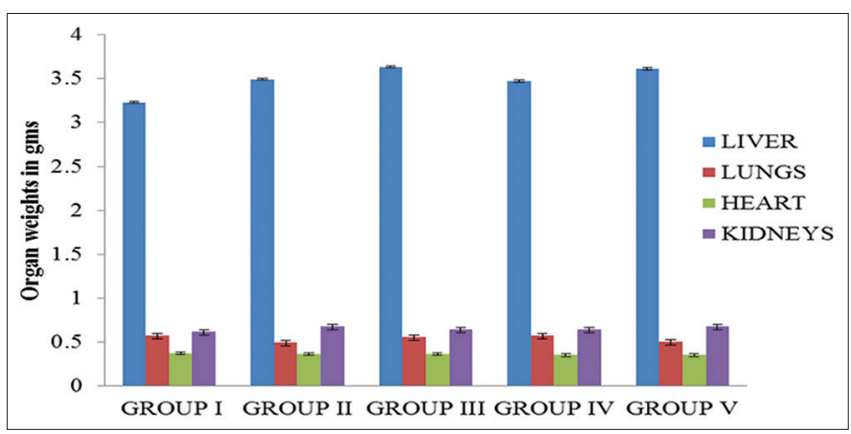

Fig. 2: Effect of chloroform and methanol extracts of Barleria buxifolia on organ weights

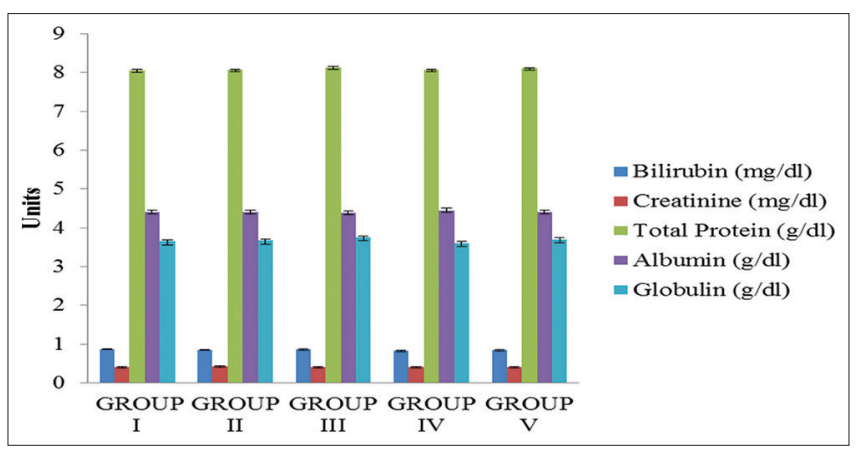

Fig. 3: Effect of chloroform and methanol extracts of Barleria buxifolia on serum biochemical parameters animals which show that chloroform and methanol extracts of Barleria buxifolia are sheltered concerning that of the electrolyte levels.

\section{Hematological parameters}

The consequences of hematological parameters, for example, RBC, WBC, platelets, hemoglobin, and MCV are recorded in Figs. 5 and 6. Administration of any chemical or medication or plant extracts can bring about loss of blood cells and/or hindrance of blood cell blend and abatement in such hematological boundaries in exploratory animals [31]. The hematological parameters, for example, RBC, WBC, platelets, hemoglobin, and mean cell volume indicated no hugeness when treated group animals are contrasted and that of control group animals. As the chloroform and methanol extracts of Barleria buxifolia do not show any huge changes in haematological parameters such as $\mathrm{RBC}, \mathrm{WBC}$, platelets, haemoglobin and mean cell volume when contrasted with control group animals will make acceptable for safe consequences for bone marrow work. [32].

\section{Histology study}

Histological investigations were appeared from Figs. 7-11 of liver, kidney, lungs, heart, and brain tissues in chloroform and methanol extracts of Barleria buxifolia treated rat's shows no irregularities and did not show any antagonistic impact on morphology when contrasted the treated and that of control. In this way, it is presumed

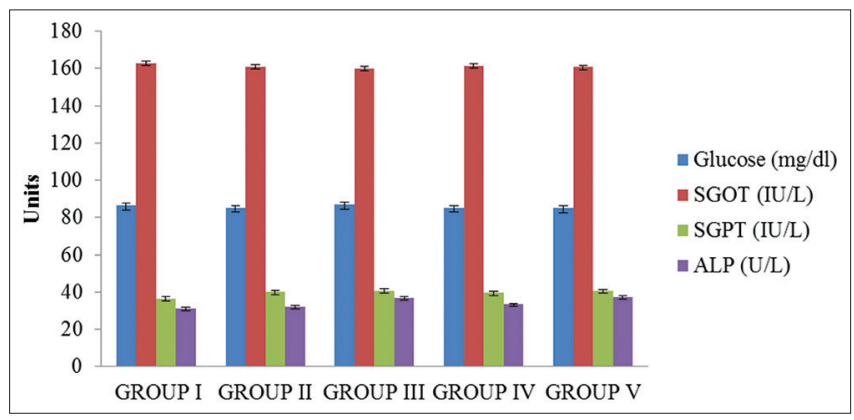

Fig. 4: Effect of chloroform and methanol extracts of Barleria buxifolia on serum biochemical parameters

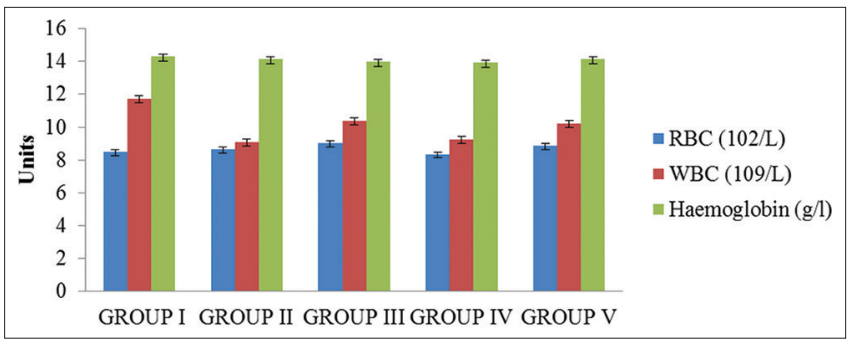

Fig. 5: Effect of chloroform and methanol extracts of Barleria buxifolia on hematological parameters

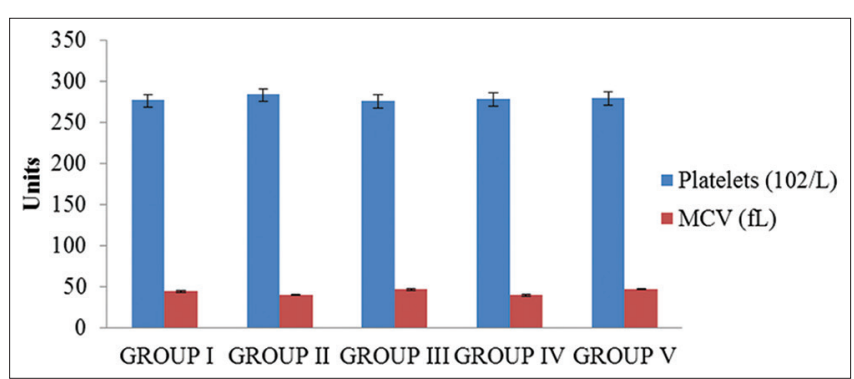

Fig. 6: Effect of chloroform and methanol extracts of Barleria buxifolia on hematological parameters 


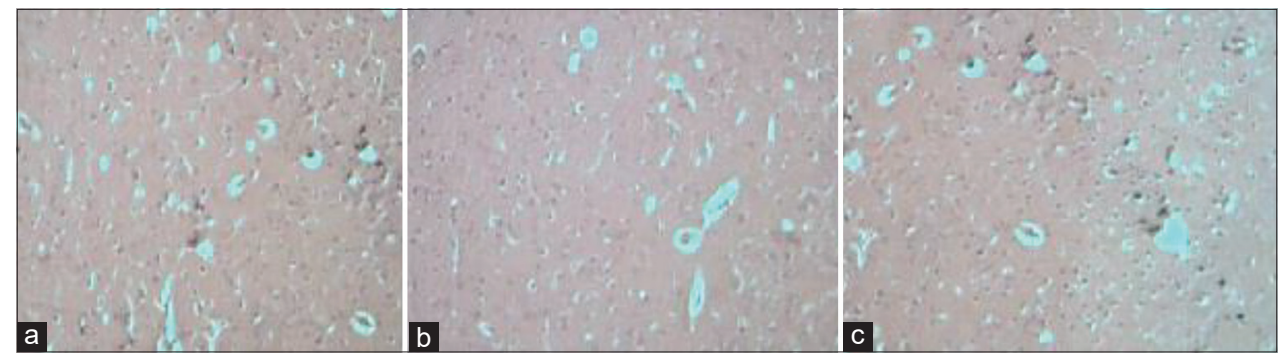

Fig. 7: Histology study of brain of rats: (a) Control group, (b) methanol extract of Barleria buxifolia, and (c) chloroform extract of Barleria buxifolia at $500 \mathrm{mg} / \mathrm{kg}$ body weight. All the brain sections show normal appearing brain matter

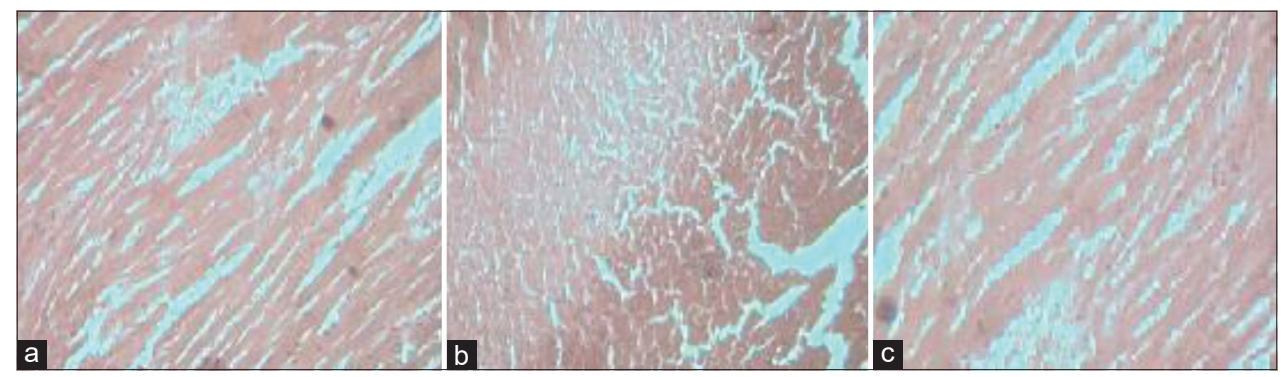

Fig. 8: Histology study of heart of rats: (a) Control group, (b) methanol extract of Barleria buxifolia, and (c) chloroform extract of Barleria buxifolia at $500 \mathrm{mg} / \mathrm{kg}$ body weight. All the sections show normal appearing myocardial fibers with focal interstitial hemorrhages and serosal congestion

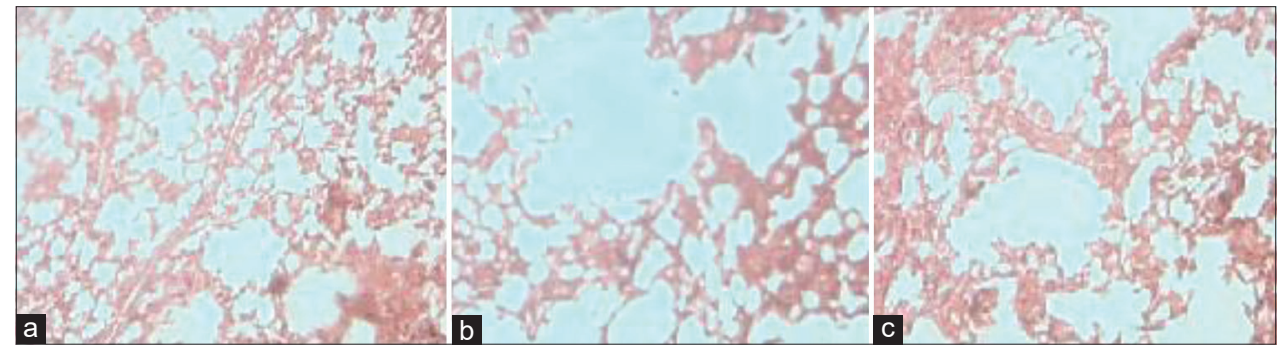

Fig. 9: Histology study of lungs of rats: (a) Control group, (b) methanol extract of Barleria buxifolia, and (c) chloroform extract of Barleria buxifolia at $500 \mathrm{mg} / \mathrm{kg}$ body weight. All the sections show normal appearing of lung matter

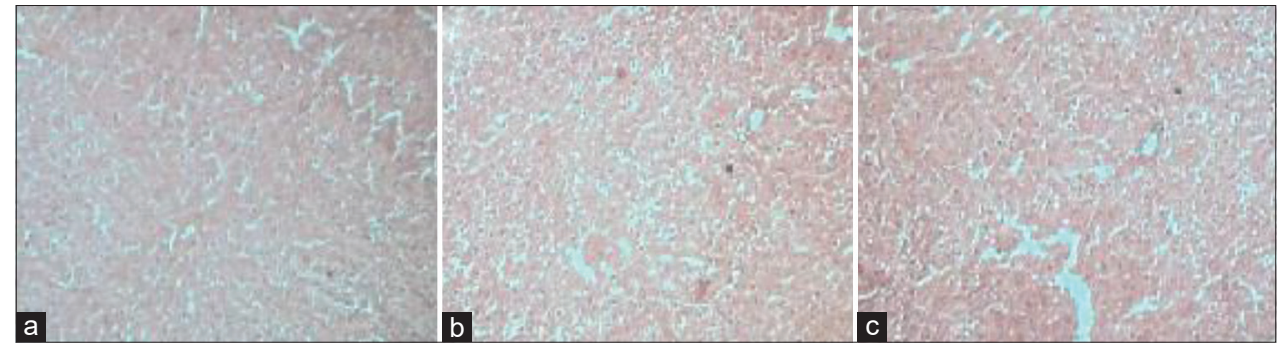

Fig. 10: Histology study of liver of rats: (a) Control group, (b) methanol extract of Barleria buxifolia, and (c) chloroform extract of Barleria buxifolia at $500 \mathrm{mg} / \mathrm{kg}$ body weight. All sections show normal lobular pattern of arrangement of normal appearing hepatocytes

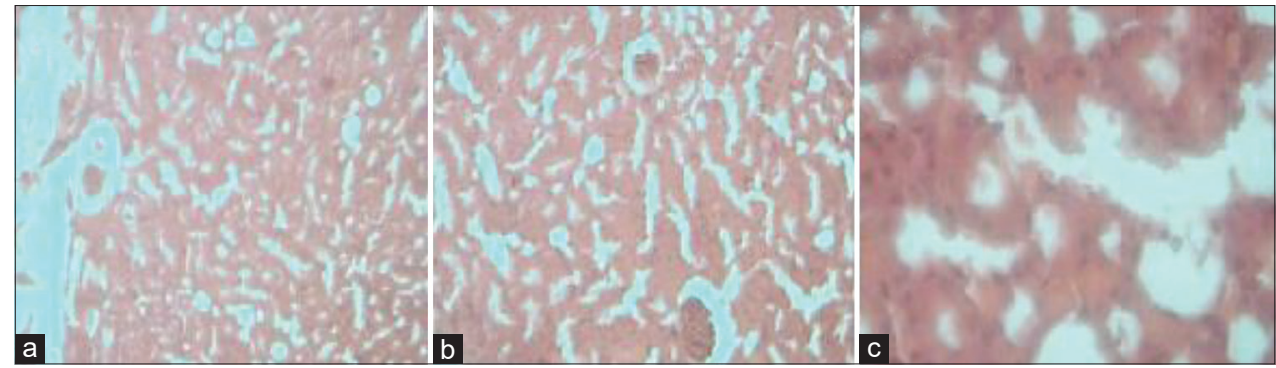

Fig. 11: Histology study of kidney of rats: (a) Control group, (b) methanol extract of Barleria buxifolia, and (c) chloroform extract of Barleria buxifolia at $500 \mathrm{mg} / \mathrm{kg}$ body weight. All sections show normal appearing glomeruli and tubules. Occasional tubular lumen showing RBC 
that Barleria buxifolia did not create any harmful impact in albino rats of either sex.

\section{CONCLUSION}

The consequences of acute oral toxicity study and subchronic toxicity investigation of chloroform and methanol extracts of Barleria buxifolia show no noteworthy contrasts in hematological and biochemical tests in the treated groups on contrasted and that of control and it will propose the degree of well-being of Barleria buxifolia on animals. With our insight, we reason that it is the primary examination of the different parameters of toxicity considers made on Barleria buxifolia at higher do. In this way, the outcomes show that the chloroform and methanol extracts of Barleria buxifolia might be sheltered and furthermore give the data to the utilization of Barleria buxifolia for additional examinations and as an elective arrangement of medication.

\section{ACKNOWLEDGMENTS}

The authors are sincerely thankful to the administration of GITAM (Deemed to be University), Visakhapatnam, and management of P. Rami Reddy Memorial College of Pharmacy, Kadapa, Andhra Pradesh, India, for giving vital offices to complete the research work.

\section{CONFLICTS OF INTEREST}

The authors declare that there were no conflicts of interest in this research.

\section{FINANCIAL SUPPORT}

None.

\section{REFERENCES}

1. David A, Enegide C. The importance of toxicity testing. J Pharm Biosci 2013;4:146-8

2. Gandhare B, Kavimani S, Kapoor BR. Acute and subacute toxicity study of methanolic extract of Ceiba pentandra (Linn.) Gaertn. on Rats. J Sci Res 2013;5:315-24

3. Balkwill MJ, Balkwill K. A preliminary analysis of distribution patterns in a large pantropical genus, Barleria L. (Acanthaceae). J Biogeogr 1998:25:95-110.

4. Tasnuva S, Shahanaz A, Farhana I. Biological activities of Barleria cristata. Int J Res Pharmacol Pharmacother 2013;2:367-71.

5. Shanaz B, Arunachalam G, Jayaveera KN, Ashoka BV, Vimal K. Antidiabetic effect of two species of Barleria in streptozotocin induced Type-II diabetic rats. Int Res J Pharm 2012;3:185-8

6. Lakshman KD, Siva SS, Vasudeva RN. Anti-inflammatory activity of ethanolic extract of Barleria gibsoni in carrageenan induced albino Wistar rats. Am J Pharmtech Res 2014:4:1-8.

7. Firoj AT, Harinath NM. Anthelmintic activity of leaves extract of Barleria gibsoni Dalz. against Pheretima posthuma. J Pharmacogn Phytochem 2016;5:250-2.

8. Natarajan D, Gomathi M, Yuvarajan R. Phytochemical and antibacterial evaluation of Barleria montana Nees. (Mountain Barleria). Asian J Pharm Clin Res 2012;5:44-6.

9. Mazumder PM, Sasmal D, Choudhary RK. Wound healing potential of the leaf extracts of Barleria cuspidata Heyne Ex Nees. Pharmacologyonline 2009;1:357-62.

10. Tabassum SS, Rajaram C, Kumar SN, Manohar R, Reddy KR. Evaluation of hepatoprotective activity of the methanolic extract of Barleria cuspidata against $\mathrm{CCl}_{4}$ induced liver damage in experimental rats. Res J Pharm Tech 2020;13:538-42.
11. Balkwill MJ, Balkwill K. Delimitation and infrageneric classification of of Barleria (Acanthaceae). Kew Bull 1997;52:535-73.

12. Purna AC, Haritha YS, Nishitha BM, Uma VS. In vitro anthelmintic activity of Barleria buxifolia on Indian adult earthworms and estimation of total flavonoid content. Asian Pac J Trop Dis 2014;4:S233-5.

13. Jeyasankar A, Chinnamani T, Chennaiyan V, Ramar G. Antifeedant activity of Barleria buxifolia (Linn.) (Acanthaceae) against Spodoptera litura Fabricius and Helicoverpa armigera Hubner (Lepidoptera: Noctuidae). Int J Nat Sci Res 2014;2:78-84

14. Purna CA, Nishitha M, Shravanthi B, Haritha SY, Kishore KM, Baheerudddin MD. Anxiolytic and antidepressant activity of Barleria buxifolia Linn. BioMedRx 2013;1:122-4.

15. Kapilraj PK. Prophylactic and curative activity of 'Barleria buxifolia. Linn' on experimentally induced calcium oxalate nephrolithiasis in animal model. Int J Pharmacol Clin Sci 2015;4:68-75.

16. Mayur P, Nijam AK, Kamal KM. Evaluation of acute and subacute oral toxicity induced by ethanolic extract of Marsdenia tenacissima leaves in experimental rats. Sci Pharm 2017;85:29.

17. Organization of Economic Co-Operation and Development. The OECD Guideline for Testing Of Chemicals: 425 Acute Oral ToxicityFixed Dose Procedures. Paris, France: Organization of Economic CoOperation and Development: 2008. p. 17-22.

18. Charles LP, Rao KV. Acute and sub-chronic toxicological studies on methanolic stem extract of Acalypha indica Linn in albino Wistar rats. Int J Pharm Pharm Sci 2014;6:560-3.

19. Vilash V, Suja SR, Latha PG, Shine VJ, Rajasekhran S. Chronic oral toxicity studies of crude ethanolic extract and ethanolic fraction of Pellionia heyneana Wedd. leaf in Wistar rats. Int J Pharm Pharm Sci 2016;8:306-12.

20. Soon YY, Tan BK. Evaluation of the hypoglycemic and anti-oxidant activities of Morinda officinalis in streptozotocin-induced diabetic rats. Singapore Med J 2002;43:77-85.

21. Trinder P. Determination of glucose-by-glucose oxidase method. Ann Clin Biochem 1969;6:24-6.

22. Raja S, Ravindranadh K. Acute and subchronic toxicity studies of Limnophila heterophylla and Michelia champaca. Int J Res Pharmacol Pharmacother 2017;6:348-57.

23. Malloy HT, Evelyn KA. The determination of bilirubin with the photoelectric colorimeter. J Biochem 1937;119:481-90.

24. Eran BA, Noah S, Lee HG, Kamer M, Suha O, Elad S. Potential risks associated with traditional herbal medicine use in cancer care: A study of middle eastern oncology health care professionals. Cancer 2016;122:598-610

25. Kwan YP, Ibrahim D, Yeng C, Subramaniam S, Sreenivasan S. Acute and subchronic toxicity study of Euphorbia hirta L. methanol extract in rats. Biomed Res Int 2013;2013:182064.

26. Klaassen CD. Principles of toxicology. In Casarett and Doull's Toxicology: The Basic Science of Poisons. $5^{\text {th }}$ ed. New York: McGrawHill; 2001. p. 13

27. Adeneye AA, Olagunju JA. Preliminary hypoglycemic and hypolipidemic activities of the aqueous seed extract of Carica papaya Linn. in Wistar rats. Biol Med 2009;1:1-10.

28. Yu J, Wang Y, Qian H, Zhao Y, Liu B, Fu C. Polyprenols from Taxus chinensis var. mairei prevent the development of $\mathrm{CCl}_{4}$-induced liver fibrosis in rats. J Ethnopharmacol 2012;142:151-60.

29. Larrey D. Epidemiology and individual susceptibility to adverse drug reactions affecting the liver. Semin Liver Dis 2002;22:145-56.

30. Jia Z, Liu M, Qu Z, Zhang Y, Yin S, Shan A. Toxic effects of zearalenone on oxidative stress, inflammatory cytokines, biochemical and pathological changes induced by this toxin in the kidney of pregnant rats. Environ Toxicol Pharmacol 2014;37:580-91.

31. Onyeyilli, PA, Iwuoha Cl, Akinniya JA. Chronic toxicity study of Ficus platyphtlla blume in rats. West Afr J Pharmacol Drug Res 1998;14:27-30.

32. Donkor K, Okine LN, Abotsi WK, Woode E. Acute and sub-chronic toxicity studies of aqueous extract of root bark of Cassia sieberiana DC in rodents. J Appl Pharm Sci 2014;4:84-9. 